\title{
THE DYNAMICS OF REAL ESTATE FIELD OF VALUE
}

\author{
Oksana Kuryj-Wysocka, M.Sc. \\ Faculty of Geodesy and Land Management \\ University of Warmia and Mazury in Olsztyn \\ e-mail: oksana.wysocka@uwm.edu.pl \\ Jan Kuryj, PhD \\ Faculty of Geodesy and Land Management \\ University of Warmia and Mazury in Olsztyn \\ e-mail:jkuryj@uwm.edu.pl
}

Radoslaw Wisniewski, assoc. prof., PhD

Faculty of Geodesy and Land Management

University of Warmia and Mazury in Olsztyn

e-mail:danrad@uwm.edu.pl

\begin{abstract}
Property is worth only as much as market participants are willing to pay for it - that is as much as the potential of the property. Determining the potential of real estate is an extremely difficult task, because certain properties can be viewed in different ways. A person's attitude towards a given real estate finds reflection in the value of the property.

Accordingly, the value of a property appears only when there is a relation of value, such as when the property catches the buyer's attention. This article raises important issues which determine the value of real estate. It reveals the value of property as a multidimensional category (spatial, economic etc.). The concept of value is characterized by peculiar dynamics; therefore, the value of a property is also characterized by dynamic traits.

In order to confirm the above thesis it is essential to isolate the most important factors that create the "field of value" and to examine how individual determinants influence the potential of the property.

The purpose of this study is to examine whether changes in the local real estate market influence the dynamics of property values. In order to achieve this objective, research was carried out on a local real estate market. As a result of the research, indicators characterizing the dynamics of value were determined.
\end{abstract}

Key words: real estate, fields of value, attractive locations.

JEL Classification: R11, D40, C10.

Citation: Kuryj-Wysocka O., Kuryj J., Wisniewski R., 2014, The dynamics of properties' 'valuable areas', Real Estate Management and Valuation, vol. 22, no. 4, pp. 105-113.

DOI: $10.2478 /$ remav-2014-0041

\section{Introduction}

Price and market dynamics are not identical concepts. Literature lacks a concept which would include both of these dynamics. In the following article, the authors make an attempt to determine how the processes occurring in the given market may affect property value. Real estate value is a concept 
which reflects both price and market dynamics. It is a multidimensional category (spatial, economic, investment), which presents the value and potential of property. The value of real estate can be considered in different ways; however, the basic issue is to determine the field in which it will be analyzed. The concept of a "field of value" has been introduced for the purpose of the following article. The field of value is not a permanent concept; it is subject to constant changes with the passage of time and in response to changes on the local real estate market. Therefore, real estate located in a given area is also characterized by certain dynamics and, as a result, its potential can have a growing or decreasing tendency. Research was conducted in chosen villages located in different gminas (communes) of Olsztyn Poviat (District). It was carried out in order to confirm the above thesis and to examine the influence of processes occurring on the local real estate market on the dynamics of the area of real estate value.

\section{Dynamics of the real estate market}

System dynamics is a more and more universal concept in different fields of science. However, despite giving enormous possibilities, it is only occasionally applied in the examination and analysis of the real estate market (DACKO 2009, p. 21). WRZOSEK (1998) claims that until relations between elements of a market change, balance (the state in which the intentions of buyers coincide with the intentions of sellers) may be theoretically characterized a high degree of stability (ability to return to a steady-state). In fact, these relations are not permanent and change when at least one of the elements of the market increases or decreases in relation to the state ensuring balance. Particular elements of a market may change not only under the influence of the interdependence which exists between them, but also under the influence of extrinsic factors which constitute the surroundings of the market (DUBINET et al. 1999, pp. 79-96). The real estate market is the resultant of many factors in this system, both external and internal. Therefore, any attempt to describe the phenomena in this market segment leads to an examination of many variables, both quantitative and qualitative in nature (PAVLOV AD 2000, pp. 249283).

The dynamics of the real estate market should be understood as a change of property values under the influence of market and non-market factors, as well as under the real estate surroundings. Dynamics of the real estate market can have different values which will depend, among others, on the trade cycle, product life cycle and macroeconomic indicators. On the account of its characteristics, real estate is regarded as one of the barometers of opportunistic changes (RHENIUM, YUAN 2014, pp. 323341). This phenomenon is mainly connected with the long-term duration of delivering the product (real estate) to the market.

Based on the time needed for planning and construction, the biggest investors try to act in advance and begin a construction before other operators observe an economic recovery and report the demand for commercial and residential surfaces.

An analysis of the real estate market based on trade cycles can serve as a good example of real estate market dynamics. In different phases of the trade cycle, the value of real estate will be subjected to substantial changes, which will result in the decreasing or increasing dynamics of the field of property value. The life cycle of a product (property) on the market is further evidence of real estate market dynamics. Property is characterized by various levels of value at different stages of its life cycle, which result from the ageing process of the building; as a general rule the price and the utility of a building will decrease continuously. However, in the case of land properties, each phase of development associated with their building development, expansion and/or modernization will result in an increase in their value. The functioning of various cycles for each segment of the market is yet another example of the existence of dynamics on the real estate market. Most analyses have been devoted to cycles of rents (tenant market), building cycles (market of building developers) and cycles of capital values. Cycles of the land market are the least recognized, although their role may be fundamental (KUCHARSKA-STASIAK 2006, pp. 104-105). Basic macroeconomic indicators, i.e. gross domestic product, interest rates, inflation rates, which in some way influence house prices, affect the dynamics of the real estate market.

Bearing in mind the above, the real estate market should not be treated only as a sum of real estate transactions on a national scale or appropriate regional unit, since it is a multidimensional category which depends on various micro- and macroeconomic factors and is characterized by specific dynamics (DIPASQUALE, WHEATON 1996, pp. 34-59). 


\section{Real estate value and its optimal use}

Value is the ratio of a person to an object (real estate). Therefore, the value of an object appears only when a relation of value arises, i.e. when a person becomes interested in an object (ADAMICZKA, 2011, p. 26). The appearance of the relation of value largely depends on the potential of the real estate and the optimal method of exploiting it. The concept of the optimal method of exploiting a given real estate is based on the assumption that, even if two or more real estates can have similar physical properties, there are important differences in the possible means of exploiting them. The mean in which real estate can be optimally used constitutes the basis for determining its potential.

The article introduces the author's own indicators of real estate value, which consider variables characterizing the current state of real estate stocks as the basis of shaping the future needs and potential supply on the market. It was also acknowledged that demographic variables constituted a crucial element of the real estate market environment, since every person exhibits a demand for property. If a person is creditworthy or has adequate financial means, they can be converted into demand (LIESER, GROH 2014, pp. 611-659). That is why the existing stock of real estate together with the demographic potential create a base which, when stimulated by a supralocal financing mechanism and an economic climate that supports investments, actuates the local potential of a given area (Postillion, 2009, pp. 8).

The potential of the real estate covers different phases of the real estate cycle, i.e. investments in real estate, property management, liquidation of real estate (ŚLIWIŃSKI 2000, pp. 56). All of them make a substantial contribution to real estate financing. The purchase of a property and its preliminary development concept are the result of the existence of the value relation. The next stage involves investments in terms of construction, i.e. those associated with building development, modernization, expansion, as well as indirect investments - in ownership rights (to real estate). An appropriate course of action regarding the implementation of repairs or modernization at a suitable time may cause an increase in real estate value (and conversely, an inappropriate course of action can lead to a decrease), oftentimes slowing or even halting the decrease in the price and utility of the real estate.

\section{Land value as a tool for determining the dynamic indicators of the real estate market}

Land value is a multidimensional category which reveals the value of a property; it is characterized by specific dynamics and therefore, market value is also determined by those dynamics. Literature differentiates the following fields of value: central (normal), monocentric, polycentric, blemished and zonal (ADAMCZEWSKI 2011, pp. 42-43). The central field is usually idealized, e.g. prices of land that is in perpetual usufruct and state-owned. The monocentric field has one attractive point which is surrounded by layers of value. The polycentric field has a few attractive points in the form of municipal "subcenters". Lastly, the blemished field is characterized by great spatial irregularity, whereas the zonal field is usually generated by official planning decisions.

The "creation" of land value is determined by certain attributes of the real estate, with price being one of the many factors shaping this field. The first group of attributes includes: market factors, i.e. location, the price of $1 \mathrm{~m}^{2}$, accessibility of public transport, surface area, technical condition of the building and technical infrastructure (territorial development network). The second group contains non-market factors, i.e. trendiness, safety, prestige and behavioral aspects. The third group includes environmental factors of the real estate, i.e. the neighborhood, infrastructure, and proximity of public institutions, retail and service outlets, recreation areas, etc.

Furthermore, the field of value can be generated by the real estate itself or by adjacent real estate, e.g. the construction of a road in the nearest surroundings will swing the value of property, but in order to assess the direction of this change one should analyze other aspects of this investment, such as traffic intensity. Moreover, certain interactions may occur between fields of value, i.e. a infiltration between fields of value, inception of new ones, the extension or disappearance of former fields of value, replacing some fields with others which contain different features, e.g. when the real estate function is changed. The field of value is a specific tool for determining the indicators of real estate market dynamics. It should be a kind of matrix which can be applied to various areas, e.g. a polycentric field is characterized by different values of indicators than a monocentric one. The dynamics of the field of value of real estate located in a given area are determined on the basis of the values of these indicators. In this article, the indicators of the dynamics of a field of value were divided into two groups. The first group contains indicators of local value, i.e. the attractiveness of the 
gmina, real estate prices, human resources, tourist accommodation or the income of the gmina, which were calculated on the basis of statistical data and preceded by an in-depth analysis of the explored gminas. The second group consists of indicators depicting the dynamics of the local real estate market, i.e. the price evolution indicator or the indicator of the dispersion of prices from the average, as well as the supply and location indicator, which were calculated on the basis of data acquired from the market.

\section{Dynamics of land value (determining the indicators)}

In order to realize the aim of the work, a study was carried out on the prices of land located in chosen villages of six gminas within Olsztyn Poviat; five of them constituted rural gminas (Dywity, Gietrzwałd, Jonkowo, Purda, Stawiguda) and one of them was the urban-rural gmina of Barczewo. Since the study was conducted on the gminas of Olsztyn Poviat, Olsztyn was excluded from the analysis so as to avoid the dominance of the city and concentrate on less urbanized areas. Leaving the agglomeration as a separate unit would have resulted in the excessive diversification of the examined objects. The time interval covered the years 2012-2014. The analysis included agricultural areas, building and commercial-service areas and garden allotments (in some villages), located in the area of the above-mentioned six gminas of Olsztyn Poviat. The localization of the explored gminas has been presented in Figure 1. They were selected solely on the basis of whether they directly bordered Olsztyn.

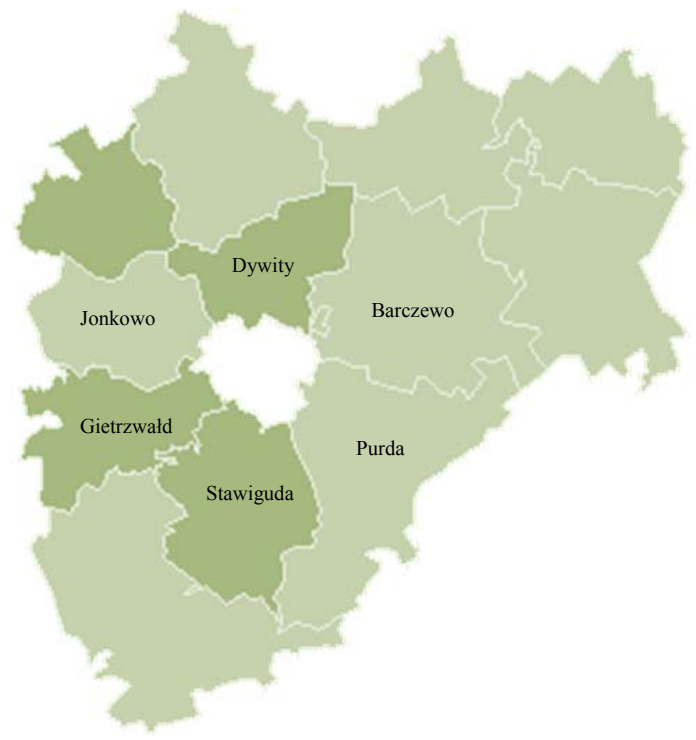

Fig. 1. Selected gmina of Olsztyn Poviat. Source: www.pkw.org.pl.

The first phase of the study was to analyze the sale prices of real estate in the analyzed areas within the villages of the individual gminas and to identify factors determining their price. The minimum, maximum and average prices observed in the individual villages of the explored gminas were aggregated to the level of each gmina and have been illustrated in Figure 2. As it is shown on the graph, the highest level of average prices characterized the gmina of Stawiguda, whereas Jonkowo and Barczewo Gminas were characterized by the lowest average prices. A similar situation was observed in case of the lowest and the highest average prices in the individual villages, aggregated to the level of examined gminas.

The second stage was to indicate attractive locations in the selected gminas and analyze the fields of value in the individual villages. Four indicators depicting the dynamics of the local real estate market were designated. Those indicators allowed us to evaluate: the price level of real estate located in villages within the individual gminas (Wn1), the dispersion of prices compared to the average price (Wn2), the supply dynamics of properties in the individual towns (Wn3) and the location attractiveness of the individual towns relative to the city of Olsztyn (Wn4).

The real estate price indicator (Wn1) was calculated for the individual villages in the given gmina by taking the ratio of the average unit price calculated for the villages and standard deviation estimated on the basis of the average unit prices of all villages in the given gmina, according to the following formula: 


$$
W n 1=\frac{\text { Cavg }}{\delta}
$$

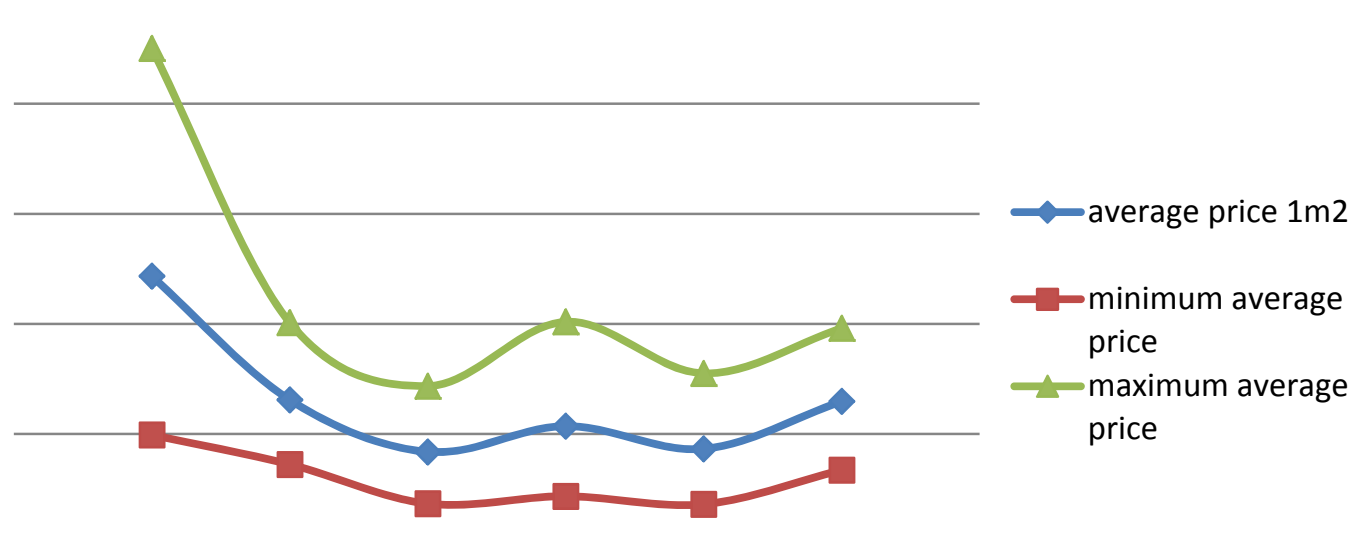

Fig. 2. Aggregated sales prices of $1 \mathrm{~m}^{2}$ of surface area in the examined gminas. Source: own study.

The final value of the indicator for each gmina was established as the average amount calculated on the basis of indicators for individual villages within the given gmina.

The indicator of price dispersion relative to the average price (Wn2) was calculated for each village of the given gmina as the difference between the maximum and minimum price per $1 \mathrm{~m}^{2}$ divided by the average unit price for the village.

$$
W n 2=\frac{\text { Cmax }- \text { Cmin }}{\text { Cavg }}
$$

The indicator of the dynamics of the supply of real estate in the individual villages (Wn3) was calculated as the ratio of the number of transactions that took place in the given villages to the average number of transactions for the gmina. The final value of the indicator for a given gmina constitutes the average value calculated from the indicators of villages within it.

The indicator of the location attractiveness of the individual villages in the gmina (Wn4) was calculated on the basis of comparing the distance from the villages to the center of the poviat (the City of Olsztyn) and the distance to the center of Olsztyn from the town that is the registered office of the gmina, according to the formula:

$$
W n 4=\frac{\text { distance from the town (being the registered office of the gmina) to the city }}{\text { distance from the given village to the city center }}
$$

The final value of the indicator for the gmina constitutes the average value established from the indicators calculated for the individual villages in the given gmina.

The final values of indicators depicting the dynamics of the local real estate market in the examined gminas have been summarized in Figure 3.

The purpose of the third stage was to select a base area and next, to appoint economic indicators to the analyzed gminas in comparison to the base area. Stawiguda Gmina was accepted as the base area because, based on the assessment of indicators depicting the dynamics of the local real estate market in the analyzed gminas, it was characterized by the highest sum of the above mentioned final values of indicators averaged for the level of the gmina, described in Table 1 as We10. The sum of the total values of indicators for Stawiguda Gmina amounted to 7.27. In comparison, the sum of the total values of indicators in the other examined gminas were as follows (Table 2): Gietrzwałd - 4.86; Jonkowo - 4.35; Dywity - 4.89; Barczewo - 5.48 and Purda - 6.10. The results have been presented in Table 2. The description and characteristics of the other indicators were established to evaluate the field of value - the economic indicators and the method of their measurement have been presented in Table 1. 


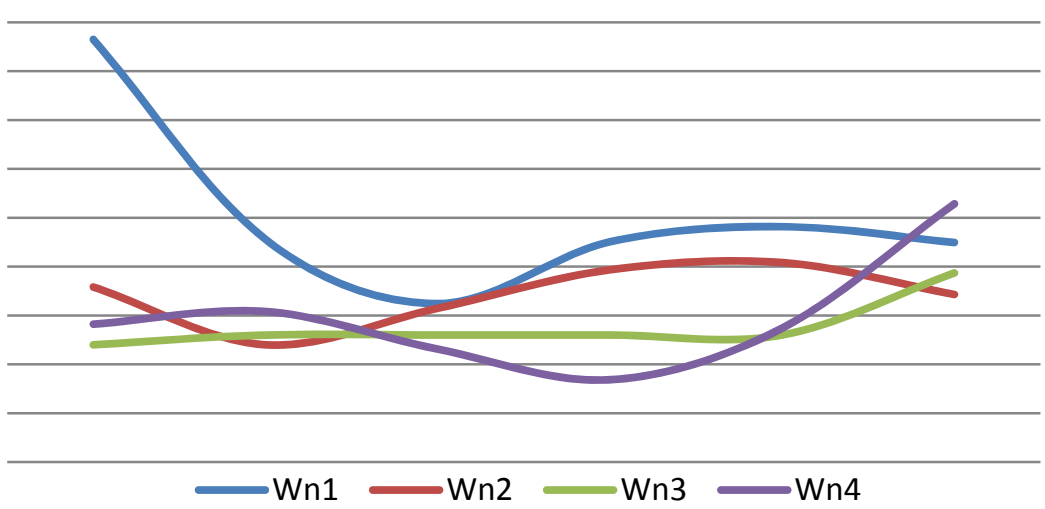

Fig. 3. Final values of indicators depicting the dynamics of the local real estate market in the examined gminas. Source: own study.

Table 1

Characteristics of examined indicators

\begin{tabular}{|c|c|c|}
\hline Indicator & Description of indicator & Method of measument \\
\hline We1 & Indicator of gmina attractiveness & $\begin{array}{l}\text { percentage of attractive locations in the } \\
\text { gmina and the average number of } \\
\text { transactions }\end{array}$ \\
\hline We2 & Indicator of transactions in the gmina & $\begin{array}{l}\text { percentage share of transactions in the } \\
\text { gmina to the total number of transactions in } \\
\text { Olsztyn Poviat }\end{array}$ \\
\hline We3 & Indicator of real estate prices & $\begin{array}{l}\text { ratio of average prices of } 1 \mathrm{~m}^{2} \text { of surface area } \\
\text { in the gmina to the average prices in } \\
\text { Stawiguda Gmina }\end{array}$ \\
\hline We4 & Indicator of human resources & $\begin{array}{l}\text { ratio of the number of residents per } 1 \mathrm{~km}^{2} \text { of } \\
\text { surface area in the given gmina to the } \\
\text { number of residents per } 1 \mathrm{~km}^{2} \text { in the base } \\
\text { gmina }\end{array}$ \\
\hline We5 & Indicator of workforce & $\begin{array}{l}\text { ratio of the number of working people to } \\
\text { the number of those unemployed in the } \\
\text { given gmina in comparison to the base } \\
\text { gmina }\end{array}$ \\
\hline We6 & Indicator of localization & $\begin{array}{l}\text { average distance of villages within a given } \\
\text { gmina to the center of Olsztyn in } \\
\text { comparison with the average distance of } \\
\text { villages in Stawiguda Gmina }\end{array}$ \\
\hline We7 & Indicator of accommodation & $\begin{array}{l}\text { ratio of the number of hotels and holiday } \\
\text { resorts in the gmina to all the objects in } \\
\text { Olsztyn Poviat }\end{array}$ \\
\hline We8 & Indicator of income & $\begin{array}{l}\text { share of income from property taxes in total } \\
\text { income of the gmina in comparison to the } \\
\text { base gmina }\end{array}$ \\
\hline We9 & Indicator of local value & sum of points from We1 to We8 \\
\hline Wn1 & Indicator of the price level & $\begin{array}{l}\text { ratio of the average price of } 1 \mathrm{~m}^{2} \text { of surface } \\
\text { area in the individual villages to standard } \\
\text { deviation }\end{array}$ \\
\hline Wn2 & $\begin{array}{l}\text { Indicator of price deviation } \\
\text { according to average price }\end{array}$ & $\begin{array}{l}\text { ratio of minimum and maximum price delta } \\
\text { to the average prices in the individual } \\
\text { villages }\end{array}$ \\
\hline
\end{tabular}




\begin{tabular}{lll}
\hline Wn3 & Indicator of supply & $\begin{array}{l}\text { ratio of the number of transactions in the } \\
\text { villages to the average number of } \\
\text { transactions in the gmina }\end{array}$ \\
\hline Wn4 & Indicator of location & $\begin{array}{l}\text { ratio of the distance from the capital of the } \\
\text { gmina to the examined village }\end{array}$ \\
\hline We10 & $\begin{array}{l}\text { Indicator depicting the dynamics of } \\
\text { the local the real estate market }\end{array}$ & $\begin{array}{l}\text { average of the sum of points from Wn1 to } \\
\text { Wn4 calculated for each gmina on the basis } \\
\text { of individual villages }\end{array}$ \\
\hline
\end{tabular}

Source: own study.

The last stage of the analysis totaled the values of indicators depicting the dynamics of the local real estate market and the values of economic indicators. They indicated the value levels in the explored gminas. The values of the analyzed indicators have been compiled into Table 2. The graphical illustration of the obtained results can be found in the graph in Figure 4.

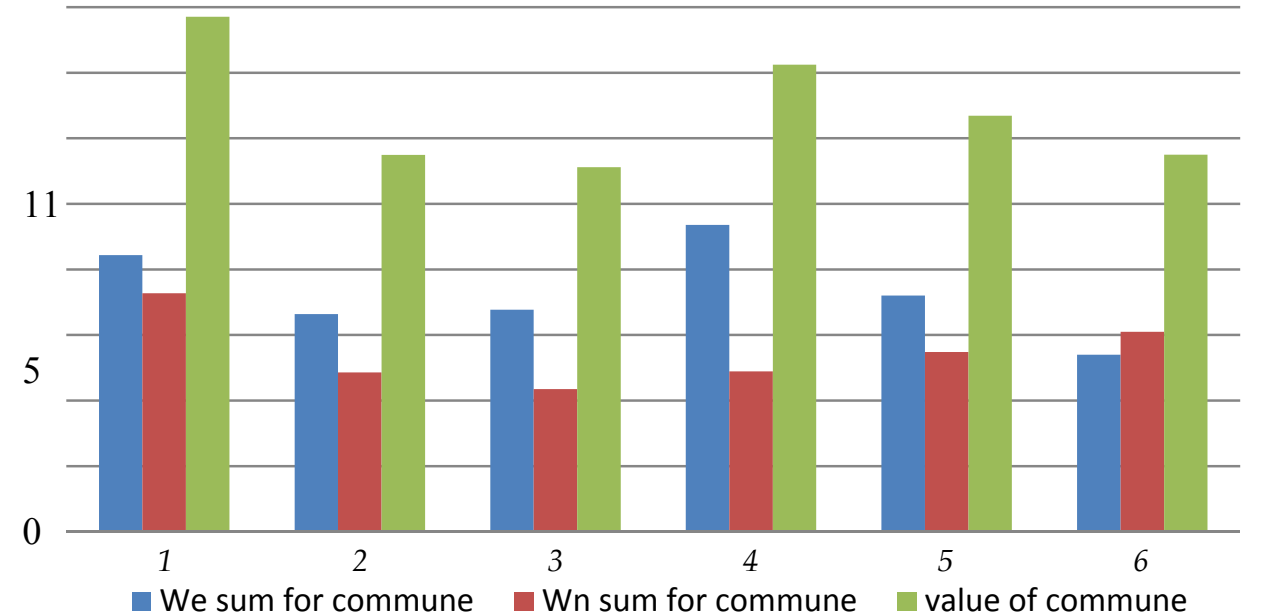

1 -Stawiguda; 2- Gietrzwatd; 3- Jonkowo; 4-Dywity; 5- Barczewo; 6- Purda

Fig. 4. Value levels of the examined gminas. Source: own study.

Table 2

List of indicators examined in the individual gminas

\begin{tabular}{ccccccc}
\hline Gmina & Stawiguda & Gietrzwałd & Jonkowo & Dywity & Barczewo & Purda \\
\hline We 1 & 3.12 & 2.19 & 2.70 & 3.55 & 2.70 & 1.86 \\
\hline We 2 & 0.18 & 0.13 & 0.17 & 0.21 & 0.16 & 0.15 \\
\hline We 3 & 1.00 & 0.54 & 0.34 & 0.44 & 0.36 & 0.53 \\
\hline We 4 & 1.00 & 1.13 & 1.28 & 2.10 & 1.70 & 0.82 \\
\hline We 5 & 1.00 & 0.67 & 1.35 & 1.06 & 0.84 & 0.29 \\
\hline We 6 & 1.00 & 0.80 & 0.69 & 1.04 & 0.49 & 0.99 \\
\hline We 7 & 0.13 & 0.17 & 0.12 & 0.12 & 0.12 & 0.12 \\
\hline We 8 & 1.00 & 1.00 & 0.13 & 0.84 & 0.84 & 0.64 \\
\hline We 9 & 8.43 & 6.64 & 6.77 & 9.36 & 7.21 & 5.40 \\
\hline Wn1 & 43.26 & 22.77 & 16.22 & 22.54 & 24.09 & 22.47 \\
\hline Wn2 & 17.91 & 12.00 & 15.74 & 19.67 & 20.41 & 17.15 \\
\hline
\end{tabular}




\begin{tabular}{ccccccc}
\hline Wn3 & 12.00 & 13.00 & 13.00 & 13.00 & 13.00 & 19.35 \\
\hline Wn4 & 14.11 & 15.40 & 11.55 & 8.42 & 13.71 & 26.43 \\
\hline $\begin{array}{c}\text { Sum of } \\
\text { indicators } \\
\text { Wn }\end{array}$ & 87.28 & 63.17 & 56.51 & 63.63 & 71.21 & 85.40 \\
\hline We 10 & 7.27 & 4.86 & 4.35 & 4.89 & 5.48 & 6.10 \\
\hline $\begin{array}{c}\text { Sum of all } \\
\text { indicators }\end{array}$ & 15.70 & 11.50 & 11.12 & 14.25 & 12.69 & 11.50 \\
\hline $\begin{array}{c}\text { Value of the } \\
\text { gmina }\end{array}$ & high & average & average & good & good & average \\
\hline
\end{tabular}

Source: own study.

The analysis reveals that properties located in the Stawiguda Gmina are characterized by the highest value, where the sum of all indicators amounted to 15.70 points, thus indicating a high development potential of the gmina. Dywity and Barczewo are equally attractive to investors. The sum of their indicators is also high, at 14.25 and 12.69 respectively, which shows a good level of property value. The lowest result in the study - 11.12 points obtained for the gmina of Jonkowo, was considered to be average in terms of development potential. Gietrzwałd and Purda Gminas were also characterized by an average level of value (11.5 points each). In the conducted study, all gminas received over 10 points; this value constituted the upper limit of the low-end value. According to these findings, the chosen gminas of Olsztyn Poviat can be valuable areas for investors operating on the real estate market. It is worth highlighting that if only local value were the subject of analysis, Dywity Gmina would have been awarded the top position and highest value, with Stawiguda Gmina ranking second; Purda Gmina would have received the lowest number of points (instead of Jonkowo), which is clearly visible in Figure 5.

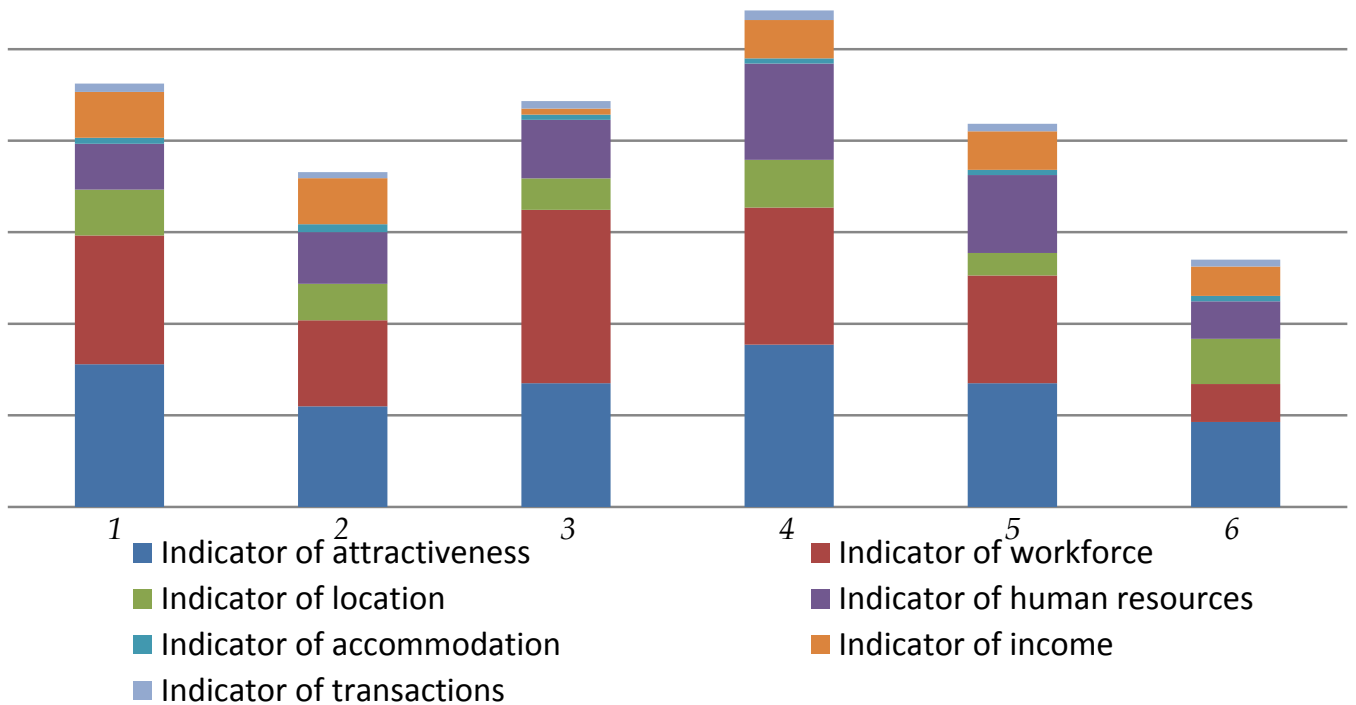

\section{1 -Stawiguda; 2- Gietrzwałd; 3- Jonkowo; 4- Dywity; 5- Barczewo; 6- Purda}

Fig. 5. Indicators of local value in the examined gminas. Source: own study.

\section{Conclusions}

In conclusion, local real estate markets are very dynamic systems. All inter-related elements (supply, demand, price) occurring in these markets are subjected to permanent changes, which has an important meaning for real estate market participants. Therefore, the analysis of the dynamic processes of the interaction between demand, supply, prices and the size of the real estate up for sale on the local market is an extremely important tool in carrying out the regional policy of a given gmina. 
The present work describes the authors' approach to analyzing the value of real estate based on the analysis of local real estate market dynamics. Based on the conducted study, it is possible to state that the indicators calculated by the authors can have significant meaning in determining the development potential of a given gmina. The obtained value levels provide a base on which local governments can make decisions regarding real estate policy. Determining the value of a given gmina makes it is possible to indicate areas where the demographic and real estate conditions are likely to encourage investors to complete new investments. Moreover, becoming acquainted with the concept of value and its dynamics can have great importance to the assessment and valorization process of the real estate market, forecasting future real estate prices, as well as when acquiring areas for private investments and for the public sector. Indicators of the dynamics of fields of value can prove to be a useful tool in terms of real estate market consulting and in procedures of mass property valuation.

\section{References}

ADAMCZEWSKI Z., 2011, Elementy modelowania matematycznego w wycenie nieruchomości. Podejście porównawcze, Warszawa.

ADAMICZKA J., 2011, Cenność przestrzeni - potencjał wykorzystania przestrzeni i jej wartościowanie [w:] Rzeczoznawca Majątkowy, nr 72, X-XII, Warszawa.

DACKO M., 2009, Dynamika systemów w modelowaniu i analizie lokalnego rynku nieruchomości [w:] Studia i Materiały Towarzystwa Naukowego Nieruchomości, vol. 17, nr 2, Olsztyn.

Dipasquale D., WheATON W. C., 1996, Urban economics and real estate markets, Prentice Hall, New Jersey.

Dubin R., PACE R. K., Thibodeau T. G., 1999, Spatial autoregression techniques for real estate data [w:] Journal of Real Estate Literature, January 1999, Volume 7, Issue 1.

FORYŚ I., 2009, Wykorzystanie analizy wielowymiarowej do oceny potencjatu rozwoju lokalnego rynku nieruchomości mieszkaniowych [w:] Studia i Materiały Towarzystwa Naukowego Nieruchomości, vol. 17, nr 2, Olsztyn.

KUCHARSKA-STASIAK E., 2006, Nieruchomość w gospodarce rynkowej, Wydawnictwo Naukowe PWN, Warszawa.

LIESER K., GROH A. P., 2014, The determinants of international commercial real estate investment [w:] The Journal of Real Estate Finance and Economics, May 2014, Volume 48, Issue 4.

PAVlov A. D., 2000, Semi-parametric approach applied to real estate markets [w:] Real Estate Economics, June 2000, Volume 28, Issue 2.

Y., YUAN Y., 2014, Why the housing sector Leeds the whole economy: the importance of collateral constraints and news shocks [w:] The Journal of Real Estate Finance and Economics, February 2014, Volume 48, Issue 2.

SENETRA A., CIEŚLAK I., 2004, Kartograficzne aspekty oceny i waloryzacji przestrzeni, Olsztyn.

ŚLIWIŃSKI A., 2000, Zarządzanie nieruchomościami podstawy wiedzy i praktyki gospodarowania nieruchomościami, Agencja Wydawnicza Placet, Warszawa.

WRZOSEK W., 1998, Funkcjonowanie rynku, PWE, Warszawa.

ZELIAŚ A. (red.), 2000, Taksonomiczna analiza przestrzennego zróżnicowania poziomu życia w Polsce w ujęciu dynamicznym. Wydawnictwo AE w Krakowie, Kraków. 